\title{
Література:
}

1. Кістяківський Б.О. Вибране. К. : Абрис, 1990. 680 с.

2. Конституция зарубежных государств: Конституция США 1787 г. M., 1996. C. 15-17.

3. Чиркин В. Е. Российская конституция и международный опыт. Государство и право. 1992. № 12. С. 13.

4. Конституции зарубежных государств : Конституция Италии 1947 г. М., 1996. 260 с.

5. Конституционное право: словарь. отв. ред. В.В. Маклаков. М.: Юристь, 2001. 166 с.

6. Цивільний кодекс України від 16.01.2003 року № 435-IV [Електронний ресурс]. - Режим доступу: https://zakon.rada.gov.ua/ laws/show/435-15\#Text

7. Цивільний процесуальний кодекс від 18.03.2004 року № 1618-IV [Електронний ресурс]. - Режим доступу: https://zakon.rada.gov.ua/ laws/show/1618-15\#Text

8. Веденеев Ю. А. Новое избирательное право РФ: проблемы развития и механизм реформирования. Вестник Центральной избирательной комиссии РФ. 1997. С. 78.

9. Ковлер А.И. Франція : партия и избиратели. М., 1984. 256 с.

DOI https://doi.org/10.30525/978-9934-588-92-1-22

\section{ДО ПИТАННЯ ЩОДО КАТАЛОГУ АБСОЛЮТНИХ ПРАВ ЛЮДИНИ В КОНСТИТУЦЙНОМУ ЗАКОНОДАВСТВІ УКРАЇНИ ТА МІЖНАРОДНИХ АКТАХ}

\author{
Дахова I. I. \\ кандидат юридичних наук, \\ дочент кафедри конституиійного права Украӥни \\ Національного юридичного університету імені Ярослава Мудрого \\ м. Харків, Україна
}

Як відомо, з огляду на можливість обмеження реалізації прав і свобод, вони поділяються на абсолютні (що не можуть бути обмежені в жодному випадку) та відносні. Аналіз Конституції та законодавства України, юридичних позицій Конституційного Суду України, а також міжнародних актів і практики ЄСПЛ, дозволяє стверджувати, що 
єдиної позиції щодо каталогу абсолютних прав не існує. Конституція України при вирішенні питання про обмеження реалізації прав і свобод виходить із принципу неможливості їх обмеження. Так, ч. 1 ст. 64 Основного Закону встановлює, що конституційні права i свободи людини і громадянина не можуть бути обмежені, крім випадків, передбачених Конституцією Украйни. Конституція України не містить переліку прав, які не можуть бути обмежені в жодному випадку, тобто переліку абсолютних прав. При цьому слід звернути увагу на те, що в Основному Законі міститься норма, в якій вказано, які саме права не можуть бути обмежені в умовах воєнного або надзвичайного стану. Так, згідно з частиною 2 статті 64 Конституції України, в умовах воєнного чи надзвичайного стану можуть встановлюватися окремі обмеження прав і свобод з зазначенням строку дії цих обмежень, що відповідає міжнародним стандартам. Так, наприклад, Згідно зі ст. 4 Міжнародного пакту про громадянські та політичні права, під час надзвичайного становища в державі, за якого життя нації перебуває під загрозою і про наявність якого офіційно оголошується, державиучасниці цього Пакту можуть вживати заходів на відступ від своїх зобов'язань за цим Пактом.

Згідно зі ст. 15 Конвенції про захист прав людини і основоположних свобод, також під час війни або іншої суспільної небезпеки, яка загрожує нації, будь-яка держава може вживати заходів, що відступають від іiі зобов'язань за Конвенцією. Однак частина 2 ст. 15 містить вказівку на те, що наведене вище положення не може бути підставою відступу від статті 2, крім випадків смерті внаслідок правомірних воєнних дій, і від статей 3,4 (п. 1) і 7, фактично визнаючи права, передбачені цими статтями, абсолютними. При цьому право на життя, закріплене статтею 2, все рівно містить виключення навіть у тексті самої ч. 2 ст. 15 Конвенції.

Повертаючись до регулювання питання можливості обмеження прав людини Конституцією України, знов звертаємось до статті 64, норма якої містить перелік прав і свобод, які навіть за наявності воєнного чи надзвичайного стану не можуть бути обмежені (право на громадянство, право на життя, право на свободу і особисту недоторканність, право на житло, право знати свої права і обов'язки, право на відмову від виконання явно злочинного розпорядження або наказу тощо). Це свідчить про те, що український законодавець відносить ці права до абсолютних. В той же час, якщо, наприклад, розглянути право на особисту недоторканність, то ч. 2 ст. 29 Конституції передбачає можливість арешту або тримання під вартою особи за вмотивованим рішенням суду на підставах і в порядку, встановлених законом. Тобто 
вказане право визнається законодавцем таким, реалізація якого за певних обставин може бути обмежена. Тієї ж думки дотримується й Конституційний Суд України, формулюючи юридичну позицію в мотивувальній частині Рішення $y$ справі за конституційними скаргами Ковтун М.А., Савченко Н.В., Костоглодова І.Д., Чорнобука В.І. щзодо відповідності Конституції України положення частини n'ятої статті 176 Кримінального процесуального кодексу України від 25.06.2019 р.: «право на свободу та особисту недоторканність не $є$ абсолютним і може бути обмежене, але тільки на підставах та в порядку, визначених законами України. Конституційний Суд України неодноразово вказував, що обмеження щодо реалізації конституційних прав i свобод не можуть бути свавільними та несправедливими, вони мають переслідувати легітимну мету, бути обумовленими суспільною необхідністю досягнення цієї мети, а також бути пропорційними та обгрунтованими. Обмеження конституційного права на свободу та особисту недоторканність має здійснюватися 3 дотриманням конституційних гарантій захисту прав і свобод людини i громадянина та виключно на підставі вмотивованого рішення» [1].

ЄСПЛ, наприклад, у рішенні у справі «Гарькавий проти України» від 18.02.2010 р. (як і у багатьох інших рішеннях), зазначив, що особа не може бути позбавлена або не може позбавлятися свободи, крім випадків, встановлених у пункті 1 cmaтmi 5 Конвенції. Цей перелік винятків $\epsilon$ вичерпним i лише вузьке тлумачення цих винятків відповідає цілям цього положення, а саме - гарантувати, що нікого не буде свавільно позбавлено свободи. Таким чином, очевидною $є$ й позиція Свропейського Суду щодо віднесення вказаного права до категорії прав, що не є абсолютними.

Дискусійним залишається питання про віднесення до абсолютних права людини на життя. Конституція України визнає його абсолютним, вказуючи на це у вже згадуваній частині 2 статті 64. Однак інша позиція знаходить відображення в Конвенції з прав людини, частина 2 ст. 2 якої передбачає випадки правомірного позбавлення життя. При цьому, як вказується у п. 37 рішення ССПЛ у справі «Pretty v. The UK», положення ст. 2 Конвенції гарантує право на життя, без якого здійснення будь-якого іншого конвенційного права та свободи виявляється недійсним. Воно визначає обмежений ряд обставин, які можуть виправдовувати позбавлення життя.

Одночасно Венеційська комісія у п. 52 Дослідження «Мірило правовладдя» до абсолютних прав відносить право на життя, заборону катування та нелюдського або такого, що принижує гідність, 
поводження чи покарання, заборону рабства, а також принцип nullum crimen, nullum poena [2].

Існує точка зору, згідно з якою Конвенцією про захист прав людини і основоположних свобод не допускається відступ також від протоколу № 6 [3], згідно зі ст. 1 якого смертна кара забороняється, і нікого не може бути засуджено до такого покарання або страчено. Однак з такою точкою зору не можна повністю погодитись, оскільки положення ст. 2 вказаного протоколу вказують на те, що «держава може передбачити у своєму законодавстві смертну кару за діяння, вчинені під час війни або неминучої загрози війни».

Аналіз практики ЄСПЛ дає змогу дійти висновку, що Суд визнає абсолютним право, передбачене статтею 3 Конвенції, тобто право на повагу гідності. У рішенні у справі «Soering v. the UK» від 8.07.1989 p. ЄСПЛ зазначає, що «стаття 3 Конвенції не знає виключень, а ст. 15 не допускає відступу від неї у період війни чи іншого надзвичайного стану, що загрожує життю нації. Це абсолютна заборона катувань чи нелюдського або такого, що принижує гідність поводження або покарання вказує, що стаття 3 втілює одну з основоположних цінностей демократичних держав, що входять до Ради Європи.

Щодо визнання права людини на повагу гідності абсолютом слід звернутись до рішення Конституційного Суду ФРН від 15.02.2006 р., в якому він визнав таким, що не відповідає Основному Закону і порушує право на людську гідність і право на життя, положення закону, що дозволяв Бундесверу збивати захоплені терористами пасажирські літаки. В даному випадку Суд виходив 3 того, що збити літак, коли терористи знаходяться на борту, означало б ставитися до пасажирів $\mathrm{i}$ членів екіпажу, взятих в заручники, як до неживих об'єктів i відчужувати жертвам невід'ємні права, що належать будь-якій людині. Даючи наказ вбивати їх для того, щоб врятувати інші життя, означало б позбавлення прав останніх. Стаття 1 Основного Закону ФРН, яка вказує, що людська гідність є недоторканною, робить неможливим намір вбивати людей в скрутному становищі на основі встановленого законом дозволу.

У рішеннях у справах «Siliadin v. France» від 26 липня 2005 р. Та «Rantsev v. Cyprus and Russia» від 7.01.2010 р. ССПЛ вказує на абсолютний характер права, передбаченого ч. 1 ст. 4 Конвенції («Нікого не можна тримати в рабстві або і підневільному стані»). Так Суд зазначає, що вказана стаття закріплює одну 3 цінностей демократичних суспільств i, на відміну від більшості матеріальноправових положень Конвенції, стаття 4 не передбачає жодних виключень із своєї дії, і держава не може відступити від своїх 
зобов'язань за цією статтею навіть за надзвичайних обставин, що загрожують життю нації.

\title{
Література:
}

1. Рішення Конституційного Суду України у справі за конституиіийними скаргами Ковтун М.А., Савченко Н.В., Костоглодова І.Д., Чорнобука B.I. щодоо відповідності Конституиії України (конституиійності) положення частини п'ятої статті 176 Кримінального проиесуального кодексу України № 7-p/2019 від 25.06.2019 p. // https://zakon.rada.gov.ua/laws/show/v007p710-19\#Text

2. Свропейська комісія «За демократію через право» Мірило правовладдя. Коментар. Глосарій. Rule of Law Checklist. Переклад 3 англійської Сергія Головатого. 2018. - C. 20.

3. Европейские стандарты в области прав человека: теория и практика функционирования Европейской Конвенции о защите прав человека и основных свобод // http://hrlibrary.umn.edu/russian/hrtsbook/ Reurostandards-Rchapter4.31.html

DOI https://doi.org/10.30525/978-9934-588-92-1-23

\section{ЗАТВЕРДЖЕННЯ ПРОГРАМИ ДІЯЛЬНОСТІ УРЯДУ В УКРАЇНІ ТА ДЕРЖАВАХ-ЧЛЕНАХ СВРОПЕЙСЬКОГО СОЮЗУ: ПОРІВНЯЛЬНО-ПРАВОВИЙ АСПЕКТ}

\author{
Зубенко Г. В. \\ кандидат юридичних наук, доцент, \\ доцент кафедри конституціийного і муніципального права \\ юридичного факультету \\ Харківського національного університету імені В. Н. Каразіна \\ м. Харків, Украӥна
}

В більшості держав-членів Свропейського Союзу, зокрема, Бельгії, Греції, Іспанії, Литві, Польщі, Португалії, Румунії, Словаччині, Фінляндії, Франції та ін. однією з умов функціонування уряду, а іноді стадією формування вищого органу виконавчої влади, $є$ схвалення парламентом програми діяльності уряду. В двопалатних парламентах програма діяльності уряду, як правило, має бути схвалена нижньою 